\title{
Restructuring vs Greenmail in The Market For Corporate Control: The Effect on Shareholder Wealth
}

\author{
Henry Stick, Finance, University of Dayton, Dayton, Ohio \\ Carl Chen, Finance, University of Dayton, Dayton, Ohio \\ Steve Dawkins, Graduate Student, University of Dayton, Dayton, Ohio
}

\begin{abstract}
The effects on shareholder wealth of the payment of greenmail versus restructuring activities to thwart hostile takeover offers were investigated and illustrated in this study. The risk premium version of the market model was used to examine abnormal security price performance relative to an event announcement for selected sample sets of companies which have employed these defense techniques. The resulting company abnormal returns were summed cross-sectionally in event-time to obtain portfolio abnormal returns for use in hypothesis testing. Evidence from prior studies is first discussed to give some insight of the effects of merger activity, capital structure changes, and greenmail announcements on shareholder wealth. Research methods and results of this analysis are then presented. Based upon the comparison of these widely used anti-takeover tactics, findings suggest that the payment of greenmail entrenches management at the expense of shareholder wealth, while restructuring activity to thwart hostile offers provides significant positive returns to shareholders.
\end{abstract}

\section{Introduction}

The market for corporate control was immensely active during 1986 and continued unabated through 1987. The "Street Talk" column from the 16 September 1987 USA Today characterized a typical trading Wednesday as follows:

Corporate raider T. Boone Pickens Jr. on Tuesday raised his tender offer for Newmont Mining Corp... from $\$ 95$ to $\$ 105$ a share. The stock leaped $55 / 8$ to close at 101 1/8. Analysts said Pickens' new offer, which came a week after his initial offer for the 28 million shares he needs for control, shows his resolve and increases pressure on Newmont managers. Analysts speculated Newmont might spin off its publicly traded Newmont Gold unit ... to Newmont Mining shareholders. But Vahid Fathi of Prescott, Ball \& Turben said it's more likely Newmont would offer new stock to London-based Consolidated Gold Fields PLC, which owns 26.2\% of Newmont, for Consolidated's USA assets, leaving
Newmont too big to swallow.

Asher B. Edelman unveiled his interest Tuesday in a long-rumored target, Foster Wheeler Corp. "I think he's trying to put this thing into play so he can get greenmail from the company... said Robert W. McCoy Jr. of Kidder, Peabody \& Co. In a filing with the Securities and Exchange Commission, Edelman said he may try for control and a breakup...

These are typical examples of battles for corporate control. Two techniques used to thwart takeovers are greenmail and restructuring by target companies. Corporate control refers to the right to manage corporate resources [Jensen and Ruback (1983)]. Control can transfer from a target firm to the board of an acquiring firm. Because boards normally delegate control to top management, control essentially transfers between competing managements of firms. When 
alternative managerial teams compete for the right to manage corporate resources, a takeover market or market for corporate control is created.

In the market for corporate control, managerial teams can compete for control via merger, tender offer, proxy contest, or elements of all three. In a merger or tender offer, the bidding firm offers to buy the common stock of the target at a premium to the target's market value. Mergers are negotiated directly with target managers and approved by the target's board of directors before going to a vote of target shareholders for approval. Tender offers are made directly to target shareholders who decide individually whether to tender their shares for sale to the bidding firm. Proxy contests occur when an insurgent group attempts to gain controlling seats on the board of directors.

Target managements respond in varying ways to hostile offers or to the threat of hostile offers. A most effective way to thwart potential offers is to operate the business in a manner which avoids its becoming a takeover candidate. This involves using assets efficiently, increasing profitability, raising cash dividends, avoiding an excessive build-up of cash and other assets and excess unused debt capacity (i.e. managing corporate resources as effectively as possible). Even with these useful strategies, still other necessary defense tactics have been developed to thwart raiders who perceive unrecognized value in a firm. Thus, development of creative anti-takeover tactics is becoming the primary task of takeover specialists in a competitive Merger and Acquisition (M\&A) fee environment. Strategies such as the "pac-man" defense, wooing a "white knight," prescribing "poison pills," packing "golden parachutes" , administering "shark repellent," paying "greenmail," and making major changes in capital structure have emerged as responses to hostile offers. Innovative anti-takeover charter amendments have also flourished in recent corporate control battles. Litigious action is becoming more common in efforts to thwart hostile bids. The focus of this study is on the payment of greenmail and on corporate restructurings because these two techniques have been widely used in recent takeover activity.

Corporate restructurings are defined as selloffs, spin-offs, untargeted share repurchases, and recapitalizations such as exchanging cash, debentures, or new common for each share of old common. Greenmail is defined as share repurchase at a premium from one individual or group posing a takeover threat. The term greenmail is used throughout this study as shorthand for the more formal "targeted share repurchase." The difference between greenmail and corporate restructuring is that greenmail involves the payment of a negotiated premium to a specific target shareholder or group, while a capital structure change directly affects all shareholders of the firm. Employment of either of these techniques should, a priori,have an effect on shareholder wealth as measured by stock price. The purpose of this study is to examine this effect and to provide managers with some decision making insight.

\section{Brief Review of Previous Research}

To examine the effect of antitakeover defenses on shareholders' wealth, two competing hypotheses (i.e. managerial entrenchment hypothesis and stockholder interests hypothesis) will be discussed. First, the managerial entrenchment hypothesis holds that either defensive restructuring or the payment of greenmail to thwart a takeover is aimed primarily at protecting incumbent management's job and decision making prerogatives at the expense of stockholders interests. With management threatened by a potential takeover, a reduction in threat results in greater managerial "perquisite consumption" at shareholder expense [Dann and DeAngelo (1983)]. According to Dann and DeAngelo, "the potential personal costs associated with a change in corporate control provide incumbent management with the incentive to use corporate resources to blunt a takeover threat." As a result, management is not inclined to take actions leading to greater effectiveness and efficiency. An increase in stockholder wealth could, therefore, not be expected.

The stockholder interests hypothesis holds that stockholders benefit from defensive strategies because the reduced threat of takeover allows management to direct its efforts to value-generating activities rather than towards those designed to discourage takeover attempts. This hypothesis postulates that a defensive strategy may result in the elimination of inefficiencies and the allocation of resources to more profitable en- 
deavors. This assumes, of course, that inefficiencies are present within the current corporate structure. Otherwise, raiders would not perceive unrecognized value in the takeover target. By reducing the inefficiencies and the costs associated with managerial competition, stockholders should gain.

In a study by Asquith (1983), the effects of merger bids on stock prices of both bidding and target companies were evaluated. Of the 91 target firms where the outcome was unsuccessful, significant positive cumulative excess returns of approximately $11 \% \quad(t=12.83)$ were noted at press day of the bid announcement. The positive returns, however, began to dwindle as uncertainty of the outcome became greater. As the uncertainty was resolved, significantly negative cumulative excess returns were seen around the termination date for the target firms. Asquith, however, did not examine the specific techniques employed by the target company to thwart the takeover.

A similar study was done by Bradley, Desai, and Kim (1983) to examine the post merger failure stock price behavior of target firms. They concluded that target firms which were unsuccessfully courted and which did not receive subsequent offers over a two year period following the failure announcement lost the initial gains noted at the time of announcement over the following two-year period. Jensen and Ruback (1983) also found that targets of unsuccessful mergers lose all positive returns associated with the offer announcement period by the time failure of the offer is known.

In summarizing these studies, it has been shown that targets of unsuccessful mergers earned significantly positive returns on the offer announcement and continued until the announcement of termination. However, the firms that did not receive additional offers in the next two years (Bradley, et al) lost all previous announcement gains. Thus, it appears that an action which eliminates a bid does not provide positive returns for stockholders in the long term, only neutral to negative returns. From these studies at least, it would be difficult to argue that actions which eliminate a bidder are in the stockholders' best interests.

Dann (1981) studied the effects of common share repurchases on shareholder wealth. He found that average common stock returns were approximately plus $15 \%$ at the time of repurchase. The positive cumulative portfolio return persisted for 60 days beyond the repurchase announcement, indicating that the positive announcement period returns are not a temporary effect. On a more general basis, Masulis (1980) studied the effects of changes in capital structure on security prices. One aspect of his work looked at the effects on common stock price of initial exchange offers proposing an increase in leverage. Portfolio returns during a two-day announcement period for 106 firms proposing an increase in leverage was plus $7.6 \% \quad(\mathrm{t}=14.6)$. Increased leverage appears to have had a significantly positive effect on shareholder wealth in the short run. Miles and Rosenfeld (1983) as well as Jain (1985) studied the effect of voluntary spin-off (sell-off) announcements on shareholder wealth. Both studies found that shareholders earn significantly positive excess returns following announcement. Although none of these studies were conducted to examine the effects of asset and capital structure change in response to a hostile offer, the results, nevertheless, provide some insight on the effects of such changes on share price and firm value.

Two studies examined greenmail payments in response to hostile takeover bids. Bradley and Wakeman (1983) studied the effects of greenmail at premium prices for 21 firms that resulted in offer termination. The three day cumulative average abnormal return surrounding the announcement of repurchase was $-5.50 \%(t=-7.14)$ for the repurchasing firm, and the cumulative average abnormal return for a 20 day period from one day before the announcement to 18 days following the announcement was $-10.5 \% \quad(t=-3$. 74). Each of the cumulative returns was significantly different from zero. These results indicated that shareholders of the repurchasing firms sustained a significant wealth-loss in the short run as a result of the repurchase.

Dann and DeAngelo (1983) also present evidence that payment of greenmail results in significantly negative stock returns for shareholders of the repurchasing firm. Of 41 large block targeted repurchases, the repurchasing firms' stock fell $1.76 \%(\mathrm{t}=-3.59)$ in a two day period surrounding the announcement. These studies, however, did not investigate the wealth impact 
for an extended period following the bid withdrawal. Therefore, little can be said about the effect of greenmail on shareholder wealth in the long term. In the short run, however, a reduction in shareholder wealth associated with greenmail suggests that such payments to eliminate takeover bidders are costly to non-participating stockholders.

Based on the above findings, it can be seen that prior studies have not examined the effect of asset and capital structure changes in response to a hostile offer nor the longer-term effect of employing various techniques. Therefore, this study was conducted to further examine the effects on shareholder wealth when capital restructuring and greenmail are used to thwart takeovers. The results should add an additional increment of knowledge to our understanding of these issues.

\section{Data Sources and Methodology}

The data consists of two sample sets of target firms which thwarted hostile takeover attempts. The first set consists of five firms that announced a major capital restructuring. The second set consists of five that used greenmail. In all ten cases, the unwanted bid was withdrawn. Although the sample is relatively small, it covers recent and large unsuccessful takeover attempts which fall into the aforementioned categories. The small sample size also allows a detailed illustration of each situation.

Each company of both samples was listed on the New York Stock Exchange. Information regarding event dates and firm selection was obtained from the Wall Street Journal Index. Since weekly data are employed in this research, the event date for the restructuring set was Friday of the week that the firm's restructuring plans were announced in the Wall Street Journal Index. The announcement of tender offer termination did not always coincide with the announcement of restructuring (See Tables 1 and 2). The tender offer termination, however, had to be a direct result of the restructuring plan. The event date for firms in the greenmail sample was Friday of the week that the targeted share repurchase was announced in the Wall Street Journal Index. This event date in these cases coincided with the announcement that the hostile bid was withdrawn.
Additional criteria were necessary for inclusion in the sample. Each company had to be relatively "clean" of additional events during the two analysis periods; that is, no extraordinary events or previous tender offers could have been noted in the Wall street Journal Index for the estimation (regression) period nor could a firm experience additional or subsequent offers from alternative bidders before and after the event date in the weeks included in the prediction period. An explanation of these analysis periods follows in the methodology brief below.

Weekly data (Friday of each week) were used in the analysis. Stock price closings and the closing value of the S\&P 500 were taken from the Standard and Poors Daily Stock Price Record. The 90-day Treasury Bill secondary market yield was obtained from the Federal Reserve Bulletin.

The risk premium version of the market model [Lintner (1965), Mossin (1966), and Sharpe $(1963,1964)]$ was used to calculate ex ante (estimation period, e) $a_{i}$ and $b_{i}$. The estimation or regression period consisted of week -82 (82 weeks before the event) to week -31 relative to the event. The model is of the form:

$\left(R_{i e}-R_{f e}\right)=a_{i}+b_{i}\left(R_{m e}-R_{f e}\right)+u_{i e}$

where $R_{\text {ie }}, R_{\text {fe, }}$, and $R_{\text {me }}$ represent returns on security $i$, the risk-free asset, and the market portfolio, respectively, over estimation period, e. $b_{i}$ is a measure of security ith systematic risk.

The second stage analysis requires the calculation of ex post (prediction period, p) abnormal excess returns (AR) for each security. The prediction period includes weeks -30 to +30 relative to the event. That is:

$$
A R_{i p}=\left(R_{i p}-R_{f p}\right)-\left(a_{i}+b_{i}\left(R_{m p}-R_{f p}\right)\right)
$$

where $R_{i p}, R_{m p}$, and $R_{f p}$ are the observed returns for security $i$, the market, and the risk free asset, respectively, in prediction time period, p. The security specific parameters $a_{i}$ and $b_{i}$ are calculated over the estimation time period, e, from equation (1).

Because the abnormal returns calculated in (2) are assumed to be independent drawings from a stationary normal distribution, standard normal 
tests or t-tests can be used for hypothesis testing. To reduce the volatility inherent in single security beta estimations, portfolio returns are the basis for the tests. Portfolios are created in event time by cross-sectionally weighting the company weekly abnormal returns.

Following Patell (1976) and Hong, Kaplan, and Mendelker (1978), a standardized abnormal return, $V_{p}$, and normalized cumulative abnormal return, $W_{L}$, for portfolios, will be used to measure changes in shareholders' wealth. Details of these statistics can be obtained from the authors upon request.

\section{Empirical Results}

The estimation (regression) period consisted of 52 weeks of data and encompassed weeks -82 to -31 relative to the event. The results are summarized in Table 3 for each of the companies in the greenmail sample set. Table 4 summarizes the results for the restructuring sample set. Comparing results presented in Tables 3 and 4 , one finds that, on average, firms in the restructuring sample set are more homogenous, and that, with the exception of CPC International and USG, firms in the greenmail sample set have a substantial amount of random risk (nonmarket related stock price volatility) as suggested by their low $R^{2}$ (coefficient of determination) values.

The prediction period consisted of weeks -30 to +30 relative to the event. Tables 5 and 7 present the standardized abnormal return, $\mathrm{V}_{\mathrm{p}}$ and normalized cumulative abnormal return (NCAR), $\mathrm{W}_{\mathrm{L}}$, along with the associated $\mathrm{t}$-statistics for each week relative to the event for the greenmail sample set and the restructuring sample set, respectively. Tables 6 and 8 present the normalized cumulative abnormal returns for selected periods surrounding the event. Figures 1 and 2 graph the NCAR for the entire 61 week prediction period. In both sample sets the normalized cumulative abnormal return is positive for every week in the prediction period but weeks -30 , -29 , and -28 .

Examining the greenmail sample, one finds that the NCAR reaches a maximum of $6.20 \%$ (significant at the $1 \%$ confidence level) one week prior to announcement that greenmail was paid and that the bid was withdrawn. The re- turns prior to that point gradually increase as the speculation of a takeover possibility becomes greater. A one week loss of $11.86 \%$ (significant at the $1 \%$ confidence level) occurs during the week of announcement, dropping the NCAR to $3.97 \%$. The week -1 to week +1 NCAR of $-3.45 \%$ is significant at the $10 \%$ confidence level. The immediate impact of the greenmail announcement appears to have an adverse effect on shareholder wealth and, thus, it supports the managerial entrenchment hypothesis for that particular period. The abnormal returns stabilize with only a slight downward trend for the 29 weeks following the greenmail announcement. The NCAR for weeks +2 to +10 and for weeks +11 to +30 are not significantly different from zero following the announcement. Although the NCAR is a positive $2.36 \%$ for the entire prediction period, it is not significantly different from zero. The wealth loss to shareholders in the weeks -1 to +1 , as a result of payment of greenmail, would support the hypothesis that management was entrenched at the expense of shareholders. The possible gains shareholders could have received had the takeover been consummated were not realized.

The NCAR for the restructuring sample set is much more dramatic prior to the announcement than for the greenmail sample set. The NCAR for the 30 weeks prior to the announcement is a positive $14.55 \%$, which is significant at the $1 \%$ confidence level. The NCAR of $9.37 \%$ is significantly positive at the $1 \%$ confidence level for weeks -30 to -11 , and an even greater NCAR of $10.57 \%$ for weeks -10 to -2 was observed. The magnitude of the abnormal return during this period is a curiosity. No single company accounts for the bulk of the abnormal return. It is interesting that the abnormal returns would be so high early on in the prediction period. One would not expect the returns to differ much from the greenmail sample set. After all, in both sample sets, the abnormal return is generated from takeover rumor, and in neither case is there any information indicating that the takeover activity will be thwarted prior to announcement. One explanation may be that the rumor might persist for a longer period of time and that sweetened offers from or increased pressure from the bidder would occur as target management is formulating the restructuring strategy. A defensive restructuring is not as quick a takeover squelcher as is the payment of greenmail (See 
Tables 1 and 2). The strategy must be formulated and in most cases approved by shareholders. This takes more time than a greenmail defense, which could allow for a longer rumor period for the accumulation of abnormal returns.

As in the greenmail sample set, the abnormal returns for the announcement week and the week following the announcement are negative. The standardized abnormal return for the announcement week was $-0.84 \%$, which is not significantly different form zero. The week following the announcement has a $V_{p}$ of $-2.63 \%$ which is not significant. The NCAR for weeks -1 to +1 was $1.51 \%$ and is not significantly different from zero. The three week announcement period returns from restructuring plans to thwart hostile offers does not support the stockholder interests hypothesis. However, the longer term effect of restructuring tells a different story. The NCAR for weeks +2 to +10 was $4.05 \%$ which is significant at the $10 \%$ confidence level, and the NCAR for weeks +11 to +30 was $8.61 \%$ which is significant at the $1 \%$ confidence level. The NCAR reaches a prediction period maximum of $16.64 \%$ at week +28 . These results indicate that restructuring to thwart a hostile bidder is in the best interest of stockholders and could be an appropriate takeover defense strategy. The preannouncement gains are not lost due to the restructuring and, in fact, show an increasing trend following the announcement.

\section{Summary and Conclusions}

The effects on shareholder wealth of greenmail payment versus restructuring activities as defenses to hostile offers in the market for corporate control were examined. Two competing hypotheses were offered to explain shareholder wealth effects of these takeover defenses. Evidence from prior studies was presented to give some insight into the effects of merger activity, asset and capital structure changes, and greenmail announcements on shareholder wealth.
Finally, an analysis which looked at abnormal security price performance of selected sample sets relative to an event announcement using the risk premium version of the market model was performed. Ex ante estimation period weekly data was used to estimate the structural parameters in a market model for each of the companies in the greenmail and restructuring samples for weeks -82 to -31 relative to the event. The ex ante betas and alphas calculated during the estimation period were then used to calculate sample set abnormal returns for a 61 week prediction period surrounding the event of interest. The company weekly abnormal returns were summed cross-sectionally to obtain portfolio abnormal returns. Hypothesis testing was performed on the resultant portfolio abnormal returns.

The results observed from the greenmail sample in this analysis are consistent with the prior work noted. Payment had a negative wealth effect in the very short run, and no significant positive return was accumulated through the 30 week period following the announcement. Greenmail entrenches management at the expense of shareholder wealth. Therefore, greenmail would not appear to be a desirable defense tactic to thwart unwanted bidders relative to the use of restructuring.

The results observed from the restructuring sample provide some new insight into this defense tactic. This study revealed that restructuring activity to thwart a hostile offer provides significant positive returns to shareholders. The significant, positive $16.25 \%$ return, accumulated through the entire prediction period ending 30 weeks following the announcement, indicates that defensive restructurings in response to hostile offers appear to be in the best interest of stockholders. This strategy is, therefore, worthy of consideration as a desirable tactic for thwarting unwanted bidders.

\section{References}

$1 \quad$ Asquith, Paul, (1983) "Merger Bids, Uncertainty, and Stockholder Returns." Journal of Financial Economics 11, 51-83.

$2 \quad$ Black, Fisher, Michael Jensen and Myron Scholes, (1972) "The Capital Asset Pricing Model: Some Empirical Tests." in Studies in the Theory of Capital Markets. Michael Jensen, Ed. (Praeger, New York, NY).

3 Bradley, Michael, Anand Desai and E. Han Kim, (1983) "The Rational Behind Interfirm Tender Offers: Information or Synergy?" Journal of Financial Economics 11, 183-206.

4 Bradley, Michael and MacDonald L. Wakeman, (1983) "The Wealth Effects of Targeted Share Repurchases." Journal of Financial Economics 11, 301-328.

5 Brown, Stephen J. and Jerold B. Warner, (1980) "Measuring Security Price Performance." Journal of Financial Economics 8 , 205-258.

6 Dann, Larry Y., (1981) "Common Stock Repurchases: An Analysis of Returns to Bondholders and Stockholders." Journal of 
7 Dann, Larry Y. and Harry DeAngelo, (1983) "Standstill Agreements, Privately Negotiated Stock Repurchases, and The Market for Corporate Control." Journal of Financial Economics 11, 275-300.

DeAngelo, Harry and Edward M. Rice, (1983) "Antitakeover Charter Amendments and Stockholder Wealth." Journal of Financial Economics 11, 329-360.

9 Drucker, Peter F., (1986) "Corporate Takeovers - What is to be Done?" The Public Interest, Winter, 3-24.

$10 \quad$ Fama, Eugene, Larry Fisher, Michael Jensen and Richard Roll, (1969) "The Adjustment of Stock Prices to New Information." International Economic Review 10, 1-21.

11 Hong, Hai, Robert S. Kaplan, and Gershon Mandelker, (1978) "Pooling vs. Purchase: The Effects of Accounting for Mergers on Stock Prices." The Accounting Review, January, 31-47.

Jain, Prem C., (1985) "The Effect of Voluntary Sell-off Announcements on Shareholder Wealth." Journal of Finance, March, 209-24.

Jennings, Robert and Michael Mazzeo, (1986) "Resisting Takeovers Isn't Always Bad." Business Horizons, March-April, 56-60. Jensen, Michael C., (1984) "Takeovers: Folklore and Science." Harvard Business Review, November-December, 109-121.

Jensen, Michael C. and Richard S. Ruback, (1983) "The Market for Corporate Control: The Scientific Evidence." Journal of Financial Economics 5, 5-50.

16 Kesner, Idalene F. and Dan R. Dalton, (1985) "Antitakeover Tactics: Management 42, Stockholders 0." Business Horizons, September-October, 17-25.

Knoeber, Charles R., (1986) "Golden Parachutes, Shark Repellents and Hostile Tender Offers." The American Economic Review 76,155-67.

Lambert, Richard A. and David F. Larker, (1985) "Golden Parachutes, Executive Decision Making, and Shareholder Wealth." Journal of Accounting and Economics 7, 179-203.

Linn, S.C., and J.J. McConnell, (1983) "An Emperical Investigation of the Impact of 'Antitakeover' Amendments on Common Stock Prices." Journal of Financial Economics 11, 361-399.

Lintner, John, (1965) "Security Prices, Risk, and Maximal Gains from Diversification." Journal of Finance 20, 587-616.

Masulis, Ronald W., (1980) "The Effects of Capital Structure Change on Security Prices: A Study of Exchange Offers." Journal of Financial Economics 8, 139-178.

Miles, James A. and James D. Rosenfeld, (1983) "The Effect of Voluntary Spin-off Announcements on Shareholder Wealth." Journal of Finance, December, 1597-1606.

Mossin, J., (1966) "Equilibrium in Capital Asset Markets" Econometrica 34, 768-783.

Patell, James M., (1976) "Corporate Forecasts of Earnings and Stock Price Behavior: Emperical Tests." Journal of Accounting Research 14, 246-276.

Regan, Patrick J., (1984) "Pension Fund Perspective: Management Responsibility in Attempted Takeovers." Financial Analysts Journal, September-October, $16+$.

Ruback, Richard S. (1982) "The Effect of Discretionary Price Control Decisions on Equity Values." Journal of Financial Economics 10, 83-105.

Saul, Ralph S., (1985) "Hostile Takeovers: What Should be Done?" Harvard Business Review, September-October, 18-24.

Sharpe, William F., (1963) "A Simplified Model of Portfolio Analysis." Management Science, January, 277-93.

Sharpe, William F., (1964) "Capital Asset Prices: A Theory of Market Equilibrium Under Conditions of Risk." Journal of Finance 19, 425-42. 


\section{FIGURE 1}

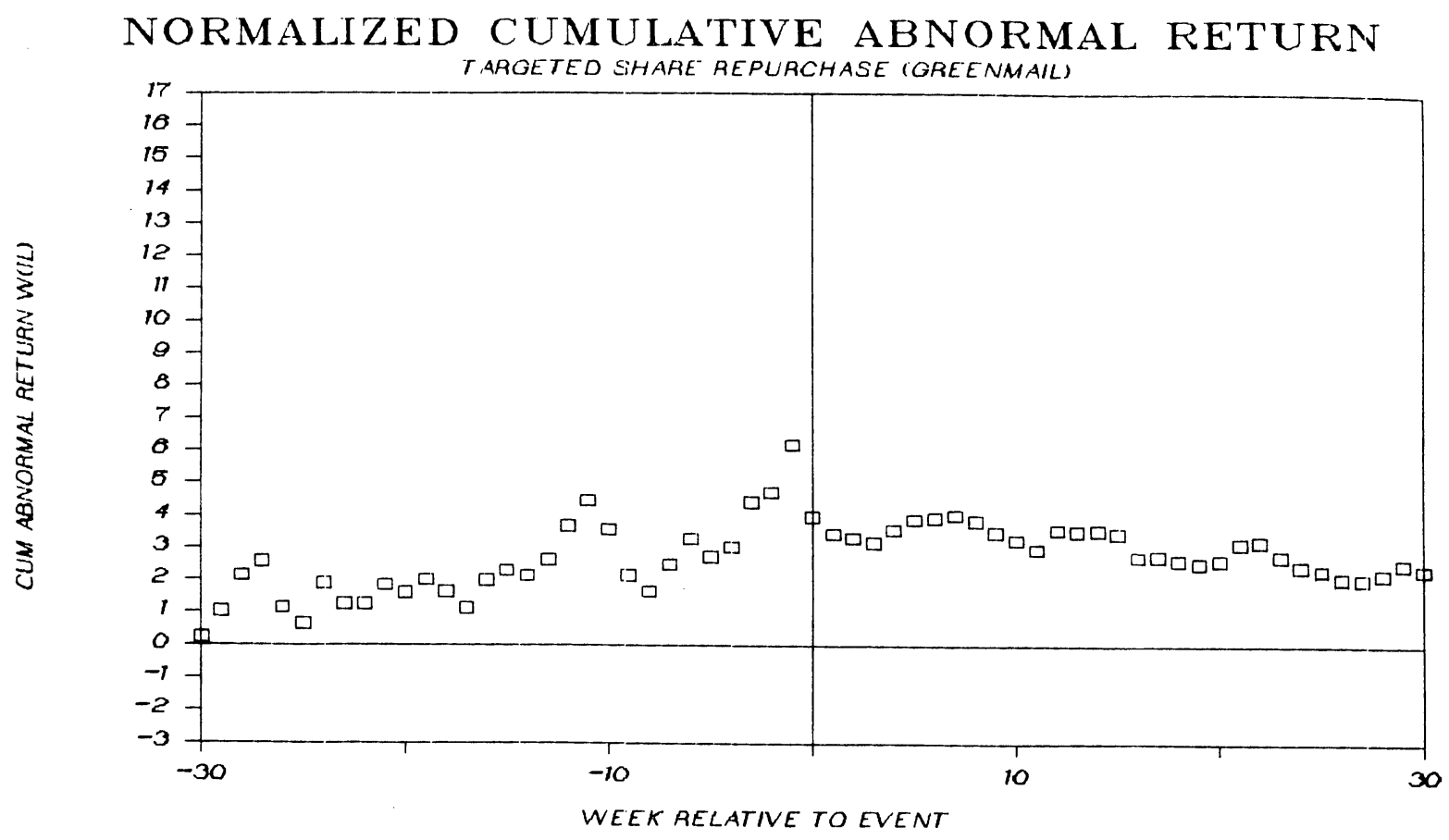

FIGURE 2

NORMALIZED CUMULATIVE ABNORMAL RETURN

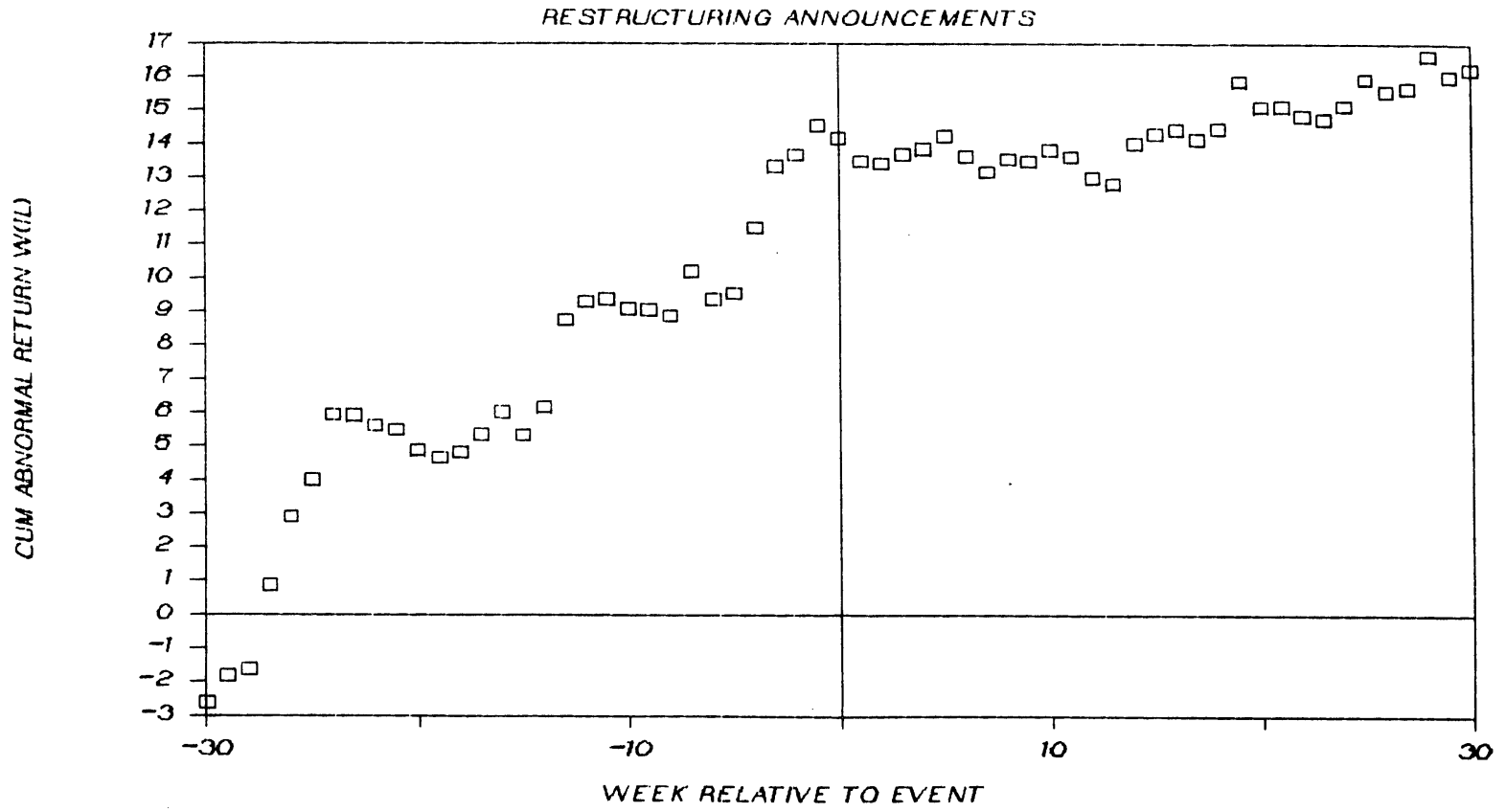


The Journal of Applied Business Research - Vol. 5, No. 2

\section{Sample Data}

TABLE 1

Greenmail Sample Set

\begin{tabular}{|l|l|r|r|}
\hline Target Company & Who Was Paid & Takeover Activity & Event Week \\
\hline Ashland Oil & & Begins & \\
\hline CPC International & Belzberg Family & $3 / 27 / 86$ & $4 / 4 / 86$ \\
\hline USG Corporation & Ronald Perelman & $10 / 14 / 86$ & $11 / 7 / 86$ \\
\hline Walt Disney & Belzberg Family & $5 / 20 / 86$ & $12 / 5 / 86$ \\
\hline Warner Communications & Saul Steinberg & $3 / 30 / 84$ & $6 / 12 / 84$ \\
\hline & Rupert Murdock & $12 / 5 / 85$ & $3 / 19 / 86$ \\
\hline
\end{tabular}

TABLE 2

Restructuring Sample Set

\begin{tabular}{|c|c|c|c|c|c|}
\hline Target Company & Bidder & Type Restructuring & $\begin{array}{r}\text { Takeover } \\
\text { Activity } \\
\text { Begins } \\
\end{array}$ & $\begin{array}{r}\text { Event } \\
\text { Week } \\
\end{array}$ & $\begin{array}{l}\text { Bid } \\
\text { Withdrawn }\end{array}$ \\
\hline CBS & Ted Turner & Untargeted Buyback & $4 / 16 / 85$ & $6 / 19 / 85$ & $8 / 6 / 85$ \\
\hline $\begin{array}{l}\text { Carter Hawley Hale } \\
\text { Stores }\end{array}$ & The Limited & Spin-off & $11 / 26 / 86$ & $12 / 12 / 86$ & $12 / 12 / 86$ \\
\hline $\begin{array}{l}\text { Owens-Corning } \\
\text { Fiberglass }\end{array}$ & Wickes Cos. & $\begin{array}{l}\text { Reorganization, Sell-off, } \\
\text { Exchange Offer }\end{array}$ & $8 / 6 / 86$ & $8 / 29 / 86$ & $8 / 29 / 86$ \\
\hline Union Carbide & GAF Corp. & $\begin{array}{l}\text { Reorganization, Sell-off, } \\
\text { Exchange Offer }\end{array}$ & $7 / 29 / 85$ & $12 / 16 / 85$ & $1 / 9 / 86$ \\
\hline UNOCAL Corp. & $\begin{array}{l}\text { Mesa Ltd. Partnership } \\
\text { (Pickens) }\end{array}$ & Exchange Offer & $2 / 15 / 85$ & $4 / 19 / 85$ & $6 / 17 / 85$ \\
\hline
\end{tabular}

Regression Statistics

TABLE 3

Greenmail Sample Set

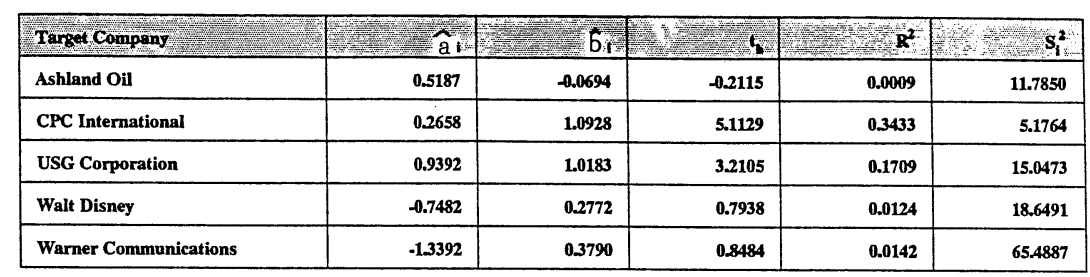

TABLE 4

Restructuring Sample Set

\begin{tabular}{|c|c|c|c|c|c|}
\hline Target Company & $=\hat{a}_{1}$ & $\mathrm{~b}_{\mathrm{t}}$ & $=5$ & $\mathrm{R}^{2}$ & $=\mathrm{s}_{\mathbf{1}}^{2}$ \\
\hline CBS & 0.2236 & 0.9571 & 6.1625 & 0.4313 & 4.8389 \\
\hline Carter Hawley Hale Stores & -0.2769 & 0.9736 & 29450 & 0.1478 & 16.0711 \\
\hline Owens-Corning Fiberglass & -0.1133 & 0.6792 & 2.61625 & 0.1248 & 5.6378 \\
\hline Union Carbide & -1.0335 & 1.2211 & 4.4803 & 0.2865 & 14.5039 \\
\hline UNOCAL Corp. & 0.4932 & 0.8621 & 2.7914 & 0.1348 & 19.8816 \\
\hline
\end{tabular}


The Journal of Applied Business Research - Vol. 5, No. 2

\section{GREENMAIL SAMPLE SET RESULTS}

TABLE 5

\begin{tabular}{|c|c|c|c|c|c|c|}
\hline $\begin{array}{l}\text { WEEK REIATIVETO TO } \\
\text { EVENT }\end{array}$ & $\mathbb{R}_{\mathrm{P}}$ & TVALUE & $\begin{array}{l}\text { CONF } \\
\text { UEVEI }\end{array}$ & 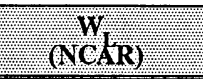 & TVAIUE & $\begin{array}{l}\text { CONF } \\
\text { WEVEL }\end{array}$ \\
\hline-30 & 0.239 & 0.105 & & 0.239 & 0.105 & \\
\hline-29 & 1.214 & 0.532 & & 1.027 & 0.450 & \\
\hline-28 & 2.229 & 0.977 & & 2.125 & 0.931 & \\
\hline-27 & 1.450 & 0.635 & & 2.566 & 1.124 & \\
\hline-26 & -2.602 & -1.140 & & 1.131 & 0.496 & \\
\hline-25 & -0.922 & -0.404 & & 0.656 & 0.288 & \\
\hline-24 & 3.431 & 1.503 & & 1.904 & 0.834 & \\
\hline-23 & -1.508 & -0.661 & & 1.248 & 0.547 & \\
\hline-22 & 0.255 & 0.112 & & 1.262 & 0.553 & \\
\hline-21 & 2.026 & 0.888 & & 1.838 & 0.805 & \\
\hline-20 & -0.501 & -0.220 & & 1.601 & 0.701 & \\
\hline-19 & 1.619 & 0.709 & & 2.000 & 0.876 & \\
\hline-18 & -1.048 & -0.459 & & 1.631 & 0.715 & \\
\hline-17 & -1.662 & -0.729 & & 1.127 & 0.494 & \\
\hline-16 & 3.492 & 1.530 & & 1.991 & 0.872 & \\
\hline-15 & 1.437 & 0.630 & & 2.287 & 1.002 & \\
\hline-14 & -0.365 & -0.160 & & 2.130 & 0.933 & \\
\hline-13 & 2.318 & 1.016 & & 2.616 & 1.146 & \\
\hline-12 & 4.987 & 2.185 & $5 \%$ & 3.691 & 1.617 & \\
\hline-11 & 3.847 & 1.686 & $10 \%$ & 4.457 & 1.953 & $10 \%$ \\
\hline-10 & -3.559 & -1.559 & & 3.573 & 1.566 & \\
\hline-9 & -6.305 & -2.763 & $5 \%$ & 2.147 & 0.941 & \\
\hline-8 & -2.161 & -0.947 & & 1.649 & 0.723 & \\
\hline-7 & 4.240 & 1.858 & $10 \%$ & 2.480 & 1.087 & \\
\hline-6 & 4.257 & 1.865 & $10 \%$ & 3.281 & 1.438 & \\
\hline-5 & -2.503 & -1.097 & & 2.727 & 1.195 & \\
\hline 4 & 1.816 & 0.796 & & 3.025 & 1.326 & \\
\hline-3 & 7.644 & 3.350 & $1 \%$ & 4.415 & 1.935 & $10 \%$ \\
\hline-2 & 2.075 & 0.909 & & 4.724 & 2.070 & $5 \%$ \\
\hline-1 & 8.496 & 3.723 & $1 \%$ & 6.196 & 2.715 & $1 \%$ \\
\hline 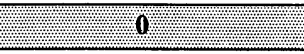 & 11.860 & 5.197 & $1 \%$ & $7 \mathrm{~g}, \mathrm{~s}$ & 1.737 & $10 \%$ \\
\hline 1 & -2.608 & -1.143 & & 3.441 & 1.508 & \\
\hline 2 & -0.455 & -0.200 & & 3.309 & 1.450 & \\
\hline 3 & -0.541 & -0.237 & & 3.168 & 1.388 & \\
\hline 4 & 2.689 & 1.178 & & 3.576 & 1.567 & \\
\hline 5 & 2.164 & 0.948 & & 3.887 & 1.703 & $10 \%$ \\
\hline 6 & 0.652 & 0.286 & & 3.941 & 1.727 & $10 \%$ \\
\hline 7 & 0.724 & 0.317 & & 4.007 & 1.756 & $10 \%$ \\
\hline 8 & -0.726 & -0.318 & & 3.839 & 1.682 & $10 \%$ \\
\hline 9 & -1.946 & -0.853 & & 3.483 & 1.526 & \\
\hline 10 & -1.224 & -0.536 & & 3.249 & 1.424 & \\
\hline 11 & -1.559 & -0.683 & & 2.969 & 1.301 & \\
\hline 12 & 4.149 & 1.818 & $10 \%$ & 3.567 & 1.563 & \\
\hline
\end{tabular}

confidence level for a two-tailed test 
GREENMAIL SAMPLE SET RESULTS (continued)

TABLE 5 (continued)

\begin{tabular}{|c|c|c|c|c|c|c|}
\hline WEEK REIATIVE TO & $V_{i}$ & IVAIUE & CONF, & $\left.W^{W} \mathbf{N}\right)$ & I-VATUE & CONEI \\
\hline 13 & -0.061 & -0.027 & & 3.517 & 1.541 & \\
\hline 14 & 0.514 & 0.225 & & 3.555 & 1.558 & \\
\hline 15 & -0.470 & -0.206 & & 3.446 & 1.510 & \\
\hline 16 & -4.575 & -2.005 & $10 \%$ & 2.742 & 1.202 & \\
\hline 17 & 0.275 & 0.121 & & 2.753 & 1.206 & \\
\hline 18 & -0.689 & -0.302 & & 2.627 & 1.151 & \\
\hline 19 & -0.486 & -0.213 & & 2.531 & 1.109 & \\
\hline 20 & 0.763 & 0.334 & & 2.613 & 1.145 & \\
\hline 21 & 3.947 & 1.729 & $10 \%$ & 3.135 & 1.374 & \\
\hline 22 & 0.678 & 0.297 & & 3.199 & 1.402 & \\
\hline 23 & -3.046 & -1.335 & & 2.754 & 1.207 & \\
\hline 24 & -2.207 & -0.967 & & 2.432 & 1.065 & \\
\hline 25 & -0.636 & -0.279 & & 2.325 & 1.019 & \\
\hline 26 & -1.602 & -0.702 & & 2.092 & 0.917 & \\
\hline 27 & -0.117 & -0.051 & & 2.059 & 0.902 & \\
\hline 28 & 1.332 & 0.584 & & 2.214 & 0.970 & \\
\hline 29 & 2.588 & 1.134 & & 2.530 & 1.109 & \\
\hline 30 & -1.151 & -0.504 & & 2.362 & 1.035 & \\
\hline
\end{tabular}

1 confidence level for a two-tailed test

TABLE 6

\begin{tabular}{|r|r|r|r|}
\hline $\begin{array}{l}\text { NCAR } \\
\text { RANGES }\end{array}$ (Weeks) & & & \\
\hline-30 to -11 & 4.457 & 1.953 & \\
\hline-10 to -2 & 1.835 & 0.804 & $10 \%$ \\
\hline-1 to +1 & -3.448 & -1.681 & \\
\hline+2 to +10 & 0.446 & 0.195 & \\
\hline+11 to +30 & -0.527 & -0.231 & \\
\hline-10 to +10 & 0.190 & 0.083 & \\
\hline-30 to +30 & 2.362 & 1.035 & \\
\hline
\end{tabular}

1 confidence level for a two-tailed test 
The Journal of Applied Business Research - Vol. 5, No. 2

\section{RESTRUCTURING SAMPLE SET RESULTS}

TABLE 7

\begin{tabular}{|c|c|c|c|c|c|c|}
\hline $\begin{array}{l}\text { WEER REVATVE TO } \\
\text { RENT }\end{array}$ & 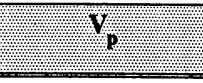 & TVALUE & $\begin{array}{l}\text { CONF } \\
\text { WEVEL }\end{array}$ & $(N C)$ & IVVALUE & $\begin{array}{l}\text { CONT } \\
\text { IEVEI }\end{array}$ \\
\hline $\mathbf{- 3 0}$ & -2.614 & -1.145 & & -2.614 & -1.145 & \\
\hline-29 & 0.047 & 0.021 & & -1.815 & -0.795 & \\
\hline-28 & -0.247 & -0.108 & & -1.624 & -0.712 & \\
\hline-27 & 4.574 & 2.004 & & 0.880 & 0.386 & \\
\hline-26 & 4.722 & 2.069 & $5 \%$ & 2.899 & 1.270 & \\
\hline-25 & 3.314 & 1.452 & & 3.999 & 1.752 & $10 \%$ \\
\hline-24 & 5.896 & 2.583 & $5 \%$ & 5.931 & 2.599 & $5 \%$ \\
\hline-23 & 1.047 & 0.459 & & 5.918 & 2.593 & $5 \%$ \\
\hline-22 & 0.117 & 0.051 & & 5.619 & 2.462 & $5 \%$ \\
\hline-21 & 0.478 & 0.210 & & 5.481 & 2.402 & $5 \%$ \\
\hline-20 & -1.149 & -0.504 & & 4.880 & 2.138 & $5 \%$ \\
\hline-19 & -0.071 & -0.031 & & 4.652 & 2.038 & $5 \%$ \\
\hline-18 & 1.252 & 0.549 & & 4.816 & 2.110 & $5 \%$ \\
\hline-17 & 2.622 & 1.149 & & 5.342 & 2.341 & $5 \%$ \\
\hline-16 & 3.300 & 1.446 & & 6.013 & 2.635 & $5 \%$ \\
\hline-15 & -1.990 & -0.872 & & 5.324 & 2.333 & $5 \%$ \\
\hline-14 & 4.100 & 1.797 & $10 \%$ & 6.160 & 2.699 & $1 \%$ \\
\hline-13 & 11.686 & 5.121 & $1 \%$ & 8.741 & 3.830 & $1 \%$ \\
\hline-12 & 3.409 & 1.494 & & 9.290 & 4.070 & $1 \%$ \\
\hline-11 & 1.399 & 0.613 & & 9.367 & 4.104 & $1 \%$ \\
\hline-10 & -0.229 & -0.100 & & 9.091 & 3.984 & $1 \%$ \\
\hline-9 & 0.813 & 0.356 & & 9.056 & 3.968 & $1 \%$ \\
\hline-8 & 0.114 & 0.050 & & 8.881 & 3.891 & $1 \%$ \\
\hline-7 & 7.374 & 3.231 & $1 \%$ & 10.199 & 4.469 & $1 \%$ \\
\hline-6 & -3.115 & -1.365 & & 9.370 & 4.106 & $1 \%$ \\
\hline-5 & 1.839 & 0.806 & & 9.548 & 4.184 & $1 \%$ \\
\hline 4 & 11.055 & 4.844 & $1 \%$ & 11.497 & 5.038 & $1 \%$ \\
\hline-3 & 10.810 & 4.737 & $1 \%$ & 13.333 & 5.842 & $1 \%$ \\
\hline-2 & $\mathbf{3 . 0 3 5}$ & 1.330 & & 13.665 & 5.988 & $1 \%$ \\
\hline-1 & 6.128 & 2.685 & $1 \%$ & 14.554 & 6.377 & $1 \%$ \\
\hline 策 & 0.835 & $=1.366$ & 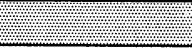 & 14.167 & 6.208 & $1 \%$ \\
\hline 1 & -2.631 & -1.153 & & 13.479 & 5.906 & $1 \%$ \\
\hline 2 & 0.827 & 0.362 & & 13.417 & 5.879 & $1 \%$ \\
\hline 3 & 2.717 & 1.190 & & 13.684 & 5.996 & $1 \%$ \\
\hline 4 & 2.091 & 0.916 & & 13.841 & 6.065 & $1 \%$ \\
\hline 5 & 3.514 & 1.540 & & 14.233 & 6.237 & $1 \%$ \\
\hline 6 & -2.578 & -1.130 & & 13.615 & 5.966 & $1 \%$ \\
\hline 7 & -1.678 & -0.735 & & 13.163 & 5.768 & $1 \%$ \\
\hline 8 & 3.400 & 1.490 & & $\mathbf{1 3 . 5 3 7}$ & 5.932 & $1 \%$ \\
\hline 9 & 0.716 & 0.314 & & 13.480 & 5.907 & $1 \%$ \\
\hline 10 & 3.143 & 1.377 & & 13.806 & 6.049 & $1 \%$ \\
\hline 11 & -0.205 & -0.090 & & 13.609 & 5.963 & $1 \%$ \\
\hline 12 & -3.001 & -1.315 & & 12.992 & 5.693 & $1 \%$ \\
\hline
\end{tabular}

1 confidence level for a two-tailed test 


\section{RESTRUCTURING SAMPLE SET RESULTS (continued)}

TABLE 7 (continued)

\begin{tabular}{|c|c|c|c|c|c|c|}
\hline 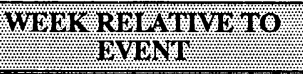 & $u_{1}^{1}$ & IVAAUE & $\begin{array}{l}\text { CONF } \\
\text { IEVEI }\end{array}$ & 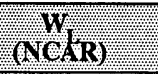 & TVAIUUE & $\begin{array}{l}\text { CONF } \\
\text { WEVEI }\end{array}$ \\
\hline 13 & -0.251 & -0.110 & & 12.806 & 5.511 & $1 \%$ \\
\hline 14 & 8.946 & 3.920 & $1 \%$ & 13.996 & 6.133 & $1 \%$ \\
\hline 15 & 3.049 & 1.336 & & 14.293 & 6.263 & $1 \%$ \\
\hline 16 & 2.000 & 0.876 & & 14.432 & 6.324 & $1 \%$ \\
\hline 17 & -1.012 & -0.443 & & 14.135 & 6.193 & $1 \%$ \\
\hline 18 & 3.221 & 1.411 & & 14.450 & 6.332 & $1 \%$ \\
\hline 19 & 11.134 & 4.879 & $1 \%$ & 15.879 & 6.958 & $1 \%$ \\
\hline 20 & -4.374 & -1.917 & $10 \%$ & 15.110 & 6.621 & $1 \%$ \\
\hline 21 & 1.131 & 0.496 & & 15.121 & 6.626 & $1 \%$ \\
\hline 22 & -1.074 & -0.470 & & 14.830 & 6.498 & $1 \%$ \\
\hline 23 & 0.264 & 0.116 & & 14.728 & 6.454 & $1 \%$ \\
\hline 24 & 3.986 & 1.746 & $10 \%$ & 15.131 & 6.630 & $1 \%$ \\
\hline 25 & 7.031 & 3.081 & $1 \%$ & 15.935 & 6.982 & $1 \%$ \\
\hline 26 & -1.764 & -0.773 & & 15.561 & 6.818 & $1 \%$ \\
\hline 27 & 1.892 & 0.829 & & 15.675 & 7.868 & $1 \%$ \\
\hline 28 & 8.473 & 3.712 & $1 \%$ & 16.644 & 7.293 & $1 \%$ \\
\hline 29 & $-\mathbf{- 3 . 7 5 8}$ & -1.647 & & 16.020 & 7.020 & $1 \%$ \\
\hline 30 & 2.798 & 1.226 & & 16.246 & 7.119 & $1 \%$ \\
\hline
\end{tabular}

1 confidence level for a two-tailed test

TABLE 8

\begin{tabular}{|r|r|r|r|}
\hline $\begin{array}{l}\text { NCAR } \\
\text { RANGES }\end{array}$ (Weeks) & W & CONFIDENCE \\
\hline-30 to -11 & 9.367 & 4.104 & LEVEL \\
\hline-10 to -2 & 10.565 & 4.629 & $1 \%$ \\
\hline-1 to +1 & 1.537 & 0.674 & $1 \%$ \\
\hline+2 to +10 & 4.051 & 1.775 & $10 \%$ \\
\hline+11 to +30 & 8.606 & 3.771 & $1 \%$ \\
\hline-10 to +10 & 10.149 & 4.447 & $1 \%$ \\
\hline-30 to +30 & 16.246 & 7.119 & $1 \%$ \\
\hline
\end{tabular}

1 confidence level for a two-tailed test 